\title{
ANALISIS PERTANYAAN GURU DALAM INTERAKSI BELAJAR-MENGAJAR BAHASA INDONESIA PADA SISWA KELAS V SEKOLAH DASAR NEGERI 7 SUSUT, BANGLI TAHUN PELAJARAN 2007/2008
}

\author{
I Nyoman Diarta \\ Program Studi Pendidikan Bahasa dan Sastra Indonesia, \\ FKIP Universitas Mahasaraswati Denpasar
}

\begin{abstract}
Teachers who do not have the skills in asking questions, who do not develop an attitude like to ask question, and who do not ask questions when carrying out the teaching-learning process, will get difficulty in directing the process of student learning. To improve the quality of the questions in the process of teaching and learning Indonesian language in elementary school is required data and information through scientific research. Therefore, this study was conducted to assess the problem as follows: (1) the type of teacher questions in the interaction of teaching and learning the Indonesian language, (2) the cognitive level of teacher questions in the interaction of teaching and learning the Indonesian language, and (3) functions of teacher questions in the interaction of teaching and learning Indonesian language.

To achieve this goal, this study uses a qualitative descriptive design. It is assigned one teacher to teach Indonesian language to fifth grade students of SD Negeri 1 Susut, Bangli. The research data collected by observation method (aided by the recording process of teaching and learning) and interview. Data analysis is done with a series of processes, namely data reduction, data presentation, and drawing conclusions.

The results of this study reveal that the teacher ask questions in the teachinglearning interaction. In terms of type, the type of narrow questions as many as 62 questions $=62.62 \%$ and the type of broad questions as much as 37 questions = $37.37 \%$. In terms of cognitive level, the knowledge questions as much as 40 questions $=43.01 \%$, the understanding questions as much as 42 questions $=45.16 \%$, the application questions as much as 2 questions $=2.15 \%$, the analysis questions as much as 1 question $=1.07 \%$, synthesis question as much as 4 questions $=4,30 \%$, evaluation question as much as 4 questions $=4.30 \%$. In terms of the function, the teacher's question is inappropriate with the function of the question in teachinglearning process.
\end{abstract}

Keywords : teacher's question, teaching-learning interaction, the type of questions, cognitive level questions, and the function of the question. 


\section{PENDAHULUAN}

\section{Latar Belakang}

Sulo, dkk. (1980:49) mengemukakan bahwa dalam melaksanakan proses belajar-mengajar, guru menggunakan tanya-jawab sebagai salah satu cara berkomunikasi dengan siswa. Pertanyaan-pertanyaan yang tersusun dengan baik dan dilontarkan dengan cara yang tepat akan: (1) meningkatkan partisipasi siswa dalam proses belajar-mengajar, (2) membangkitkan minat dan rasa ingin tahu siswa terhadap suatu masalah yang sedang dibicarakan, (3) mengembangkan cara berpikir dan cara belajar aktif dari siswa, sebab berpikir itu sesungguhnya adalah bertanya, (4) menuntun proses berpikir murid, sebab pertanyaan yang baik akan membantu murid agar dapat menemukan jawab; 1 lang baik, dan (5) memusatkan perhatian murid terhadap masalah yang sedang dibahas. Oleh sebab itu, keterampilan serta kelancaran bertanya guru perlu ditingkatkan, baik pada aspek isi maupun pada aspek teknik bertanya.

Berdasarkan hasil wawancara peneliti dengan guru yang mengajar di kelas V Sekolah Dasar Negeri No 7 Susut, Bangli pada observasi awal, ternyata guru tidak melakukan perencanaan dari awal mengenai pertanyaan yang diajukan dalam interaksi belajar-mengajar bahasa Indonesia. Guru mengajukan pertanyaan secara spontan sesuai dengan situasi dan kondisi belajar-mengajar pada saat itu. Pertanyaan yang diajukan oleh guru kepada siswa dalam interaksi belajar-mengajar bahasa Indonesia lebih banyak untuk memotivasi dan mengecek pemahaman siswa mengenai materi yang diajarkan.

Berdasarkan latar belakang masalah, di atas, berikut ini dapat dirumuskan masalah penelitian sebagai berikut.

1) Bagaimanakah tipe pertanyaan guru dalam interaksi belajar-mengajar Bahasa Indonesia pada siswa kelas V SD Negeri No 7 Susut, Bangli?

2) Bagaimanakah tingkatan kognitif pertanyaan guru dalam interaksi belajarmengajar bahasa Indonesia pada siswa kelas V SD Negeri No 7 Susut, Bangli? 
3) Apakah fungsi pertanyaan guru dalam interaksi belajar -mengajar bahasa Indonesia pada siswa kelas V SD Negeri No 7 Susut, Banggli?

Sesuai dengan rumusan masalah yang sudah dipaparkan di atas, berikut ini dapat dikemukakakan tujuan penelitian sebagai berikut.

1) Untuk mendeskripsikan dan menganalisis tipe pertanyaan guru dalam interakasi belajar-mengajar bahasa Indonesia pada siswa kelas V di SD Negeri No 7 Susut, Bangli,

2) Untuk mengklasifikasikan tingkatan kognitif pertanyaan guru dalam interaksi belajar-mengajar bahasa Indonesia pada siswa kelas V di SD Negeri No 7 Susut, Bangli,

3) Untuk mendeskripsikan fungsi pertanyaan guru dalam interaksi belajarmengajar bahasa Indonesia pada siswa kelas V SD Negeri No 7 Susut, Bangli.

\section{LANDASAN TEORI DAN KAJIAN PUSTAKA}

\section{Landasan Teori}

\section{Pembelajaran Bahasa Indonesia di Sekolah Dasar}

Belajar bahasa pada hakikatnya adalah belajar berkomunikasi. Oleh karena itu, pembelajaran bahasa diarahkan untuk meningkatkan kemampuan berkomunikasi siswa baik lisan maupun tertulis. Pembelajaran bahasa di sekolah dasar juga diarahkan untuk mempertajam kepekaan siswa terhadap segala peristiwa yang terjadi di lingkungannya. Siswa tidak hanya diharapkan mampu memahami informasi yang disampaikan secara lugas atau secara langsung, melainkan juga yang disampaikan secara terselubung atau tidak langsung. (Depdikbud,1991:12-15).

\section{Konsep Pertanyaan}

Secara sintaksis, pertanyaan diartikan sebagai kalimat tanya yang memiliki salah satu atau beberapa ciri berikut: (1) memiliki distribusi tanya yakni diikuti dengan ujaran yang lazim disebut dengan jawaban, (2) memiliki struktur sintaksis kalimat tanya, menggunakan kata tanya, partikel tanya atau pembalikan urutan, (3) 
memiliki intonasi tanya, dan (4) memiliki ekspresi (gesture) tanya, yaitu gerak pisik atau isyarat yang menunjukkan pertanyaan.(Rofi' uddin,1990:52).

\section{Tipe Pertanyaan dalam Pembelajaran Bahasa Indonesia}

Sehubungan dengan penelitian ini, klasifikasi tipe pertanyaan yang digunakan sebagai pegangan dalam menganalisis data adalah tipe pertanyaan sempit dan tipe pertanyaan luas menurut Richey. Tipe pertanyaan sempit, yakni tipe pertanyaan yang dapat dijawab dengan satu jawaban yang benar. Kemungkinan untuk memberikan berbagai alternatif jawaban sangat terbatas. Sebaliknya, tipe pertanyaan luas, yakni tipe pertanyaan yang memberikan kesempatan yang lebih luas bagi lahirnya responsrespons alternatif sebagai jawaban yang dapat diterima.

\section{Fungsi Pertanyaan Guru dalam Interaksi Belajar-Mengajar Bahasa Indonesia}

Masnur, M. dkk. (1987:133-134) mengemukakan bahwa berdasarkan fungsinya, pertanyaan dapat dibedakan atas: (1) pertanyaan mengarahkan, yakni suatu pertanyaan yang diajukan oleh guru kepada siswa untuk memberikan arah dalam proses berpikir sehingga murid dapat menemukan inti permasalahannya, (2) pertanyaan menggali, yakni pertanyaan lanjutan yang akan mendorong siswa untuk lebih mendalami gagasan pokok yang terdapat dalam pertanyaan semula. (3) pertanyaan memancing, yakni pertanyaan yang pada hakikatnya merupakan versi lain dari pertanyaan mengarahkan dan pertanyaan menggali, karena di dalamnya terdapat unsur-unsur mengarahkan dan menggali pendapat siswa yang bertujuan untuk memancing ide-ide siswa secara original.

\section{Taksonomi Tujuan Pendidikan Benjamin S. Bloom}

Benjamin S. Bloom dan kawan-kawannya itu berpendapat bahwa taksonomi (pengelompokan) itu harus senantiasa mengacu kepada tiga jenis domain (= daerah binaan atau ranah) yang melekat pada diri peserta didik, yaitu: (1) ranah proses berpikir (cognitive domain), (2) ranah nilai atau sikap (affective domain), dan (3) ranah keterampilan (psychomotor domain). Dalam penelitian ini ranah yang akan 
diteliti hanya terbatas pada ranah kognitif. Oleh karena itu, pembahasan secara teoretis akan dibatasi pada ranah kognitif saja.

Berdasarkan tingkatan kognitif pertanyaan yang dikemukakan oleh Benjamin S Bloom dapat dibedakan menjadi (1) pertanyaan pengetahuan adalah pertanyaan yang menuntut siswa untuk menyebutkan kembali informasi sesuai dengan yang diberikan dalam proses belajar-mengajar, (2) pertanyaan pemahaman adalah pertanyaan yang menuntut siswa untuk membuktikan bahwa mereka telah mempunyai pengetahuan yang cukup untuk mengorganisasikan dan menyusun materi yang sudah diketahui secara mantap, (3) pertanyaan aplikasi adalah pertanyaan yang meminta siswa dapat menerapkan informasi-informasi yang telah dipelajari agar dapat memecahkan suatu masalah, (4) pertanyaan analisis adalah pertanyaan yang menuntut siswa mampu, (a) mengidentifikasi motif, alasan-alasan dan sebab-sebab suatu masalah, (b) mempertimbangkan dan menganalisis informasiinformasi agar memperoleh suatu simpulan dan generalisasi berdasarkan informasi sebelumnya, (c) menganalisis suatu simpulan untuk menemukan kejadian-kejadian yang dapat mendukung atau menolak simpulan, (5) pertanyaan sintesis adalah pertanyaan yang menuntut siswa untuk mampu menyusun suatu pemikiran mandiri dan kreatif, (6) pertanyaan evaluasi adalah pertanyaan yang tidak memiliki jawaban yang mutlak dan tidak mempunyai jawaban tunggal.

Berdasarkan tinggi rendahnya kualitas pertanyaan Bloom mengklasivikasikan keenam pertanyaan tersebut menjadi dua kelompok yaitu pertanyaan yang tergolong berpikir tingkat rendah adalah pertanyaan pengetahuan, pemahaman dan aplikasi. Sebaliknya pertanyaan-pertanyaan yang tergolong berpikir tingkat tinggi adalah pertanyaan analisis, sintesis dan evaluatif.

\section{Kajian Pustaka}

Penelitian yang dilakukan oleh Gosong (1998) menekankan pada periode dan dasar pertimbangan guru mengajukan pertanyaan pada periode itu, tipe pertanyaan dan dasar pertimbangan guru memilih tipe tersebut, apakah pertanyaan yang diajukan oleh guru mampu mewujudkan interaksi yang optimal, dan apakah pertanyaan yang diajukan oleh guru dirasakan oleh siswa sebagai hal yang membantu proses pemahaman mereka atas isi bacaan. Penelitian ini dirancang dengan penelitian 
kualitatif deskriptif. Instrumen yang digunakan dalam pengumpulan data adalah observasi dan rekaman. Hasil penelitian ini menujukkan bahwa, dari segi bentuk pertanyaan yang disajikan oleh guru menggunakan kata tanya, siapa, apa, kapan, di mana, berapa, mana, yang mana. Guru juga mengajukan pertanyaan yang dijawab dengan ya atau tidak. Dari segi jenjang pemahaman, pertanyaan yang diajukan oleh guru terdiri atas jenjang pemahaman literal, inferensial, dan evaluatif. Dalam tataran peningkatan pemahaman siswa, pertanyaan yang diajukan oleh guru dimaksudkan untuk bahan apersepsi, mengecek pemahaman siswa, memperluas pengetahuan siswa.

\section{RANCANGAN PENELITIAN}

Untuk mencapai tujuan penelitian seperti yang disebutkan di atas, rancangan penelitian ini menggunakan disain kualitatif. Disain ini dipilih karena cocok dengan karakteristik masalah penelitian yakni pertanyaan guru dalam interaksi belajarmengajar yang sedang berlangsung secara alamiah di dalam kelas. Pemilihan disain ini sesuai pula dengan hakikat penelitian kualitatif yang dikemukakan oleh Bogdan dan Biklen (dalam Gosong,1998:85), yang mengatakan bahwa penelitian kualitatif mempunyai ciri latar yang alamiah. Latar yang alamiah ini merupakan sumber langsung data penelitian.

Selain sesuai dengan masalah dan tujuan penelitian ini, pemilihan disain kualitatif juga sesuai dengan klasifikasi penelitian ini yang tergolong ke dalam penelitian studi kasus pengamatan (observational case study). Dalam jenis penelitian seperti ini, fokus penelitian tertuju kepada observasi atas organisasi (seperti sekolah) atau bagian dari organisasi tersebut (misalnya kelas). Fokus utama penelitian ini adalah sekelompok individu yang berinteraksi dalam periode waktu tertentu (Brog dan Gall dalam Gosong,1983: 489). Dalam penelitian ini, fokus observasi ditujukan kepada pertanyaan yang diajukan oleh guru kepada siswa dalam interaksi belajarmengajar bahasa Indonesia di kelas.

Dalam penelitian ini yang menjadi subjek penelitian adalah guru yang mengajar di kelas V Sekolah Dasar Negeri No. 7 Susut, Bangli tahun pelajaran 2007/2008. Objek penelitian ini adalah pertanyaan guru dalam interaksi belajarmengajar bahasa Indonesia pada siswa kelas V SD Negeri No 7 Susut, Bangli. 
Pertanyaan-pertanyaan yang dianalisisis adalah meliputi, tipe pertanyaan guru, tingkatan kognitif pertanyaan guru, dan fungsi pertanyaan guru dalam interaksi belajar-mengajar bahasa Indonesia. Penelitian ini dilaksanakan di kelas V Sekolah Dasar Negeri No. 7 Susut, Bangli tahun pelajaran 2007/2008.

Data yang dicari dan dianalisis dalam penelitian ini adalah data primer, yaitu data yang langsung didapatkan dari sumber data. Data tersebut adalah data empiris berbentuk pertanyaan-pertanyaan guru yang sedang melaksanakan proses belajarmengajar di kelas V Sekolah Dasar Negeri No. 7 Susut, Bangli. Data ini nantinya akan berupa hasil rekaman yang ditranskripsikan secara fonemik, dan hasil observasi yang dilakukan oleh peneliti.

Analisisis data pada saat pengumpulan data berlangsung dilakukan secara bertahap yaitu pada setiap satu kali pertemuan pengumpulan data. Analisis data kualitatif, seperti yang dikemukakan oleh Miles dan Huberman (dalam Gosong,1998:100), terdiri atas tiga kegiatan, yaitu (1) reduksi data, (2) penyajian data, dan (3) penarikan simpulan. Ketiga alur kegiatan ini berkaitan erat satu dengan yang lainnya.

\section{HASIL PENELITIAN DAN PEMBAHASAN}

\section{Reduksi Data}

Kegiatan reduksi data telah menghasilkan data yang semakin jelas, dalam arti, data tersebut sudah sesuai dengan fokus dan masalah dalam penelitian ini. Data yang direduksi dalam penelitian ini adalah data pertanyaan yang tidak sesuai dengan fokus penelitian dan tidak berkaitan dengan materi yang diajarkan. Selama lima kali pertemuan proses belajar-mengajar, guru mengajukan sebanyak 117 pertanyaan. Dari 117 pertanyaan tersebut 18 pertanyaan yang direduksi dan 99 pertanyaan yang terpilih sebagai data penelitian.

\section{Penyajian Data dan Penarikan Simpulan}

Kegiatan reduksi data sebagaimana telah diuraikan di atas, sudah menghasilkan data terpilih sesuai dengan fokus dan masalah penelitian. Selanjutnya penyajian data dan penarikan simpulan diurut sesuai dengan rumusan masalah yaitu 
(1) tipe pertanyaan guru dalam interaksi belajar-mengajar bahasa Indonesia menurut Richey, (2) tingkatan kognitif pertanyaan guru dalam interaksi belajar-mengajar bahasa Indonesia menurut Bloom, dan (3) fungsi pertanyaan guru dalam interaksi belajar-mengajar bahasa Indonesia.

Berdasarkan hasil observasi dan rekaman di tempat penelitian yang dilaksanakan dari tanggal 3 maret 2008 sampai dengan 10 mei 2008, dari lima kali pertemuan proses belajar-mengajar dapat dikemukakan bahwa dalam setiap pelaksanaan proses belajar-mengajar, guru mengajukan pertanyaan kepada siswa. Secara keseluruhan pertanyaan yang diajukan oleh guru yang terpilih sebagai data penelitian adalah sebanyak 99 pertanyaan

\section{a. Analisis pertanyaan berdasarkan tipenya}

Berdasarkan tipenya ke- 99 pertanyaan tersebut, terdiri atas $62=62,62 \%$ tipe pertanyaan sempit dan $37=37,37$ tipe pertanyaan luas. Apabila dilihat perbandingan pertanyaan sempit dan pertanyaan luas pada masing-masing pertemuan dapat dikemukakan sebagai berikut.

Tabel 1. Tipe pertanyaan sempit dan tipe pertanyaan luas

\begin{tabular}{|c|c|c|c|c|c|c|}
\hline \multirow[t]{2}{*}{ No } & \multirow{2}{*}{$\begin{array}{c}\text { Pertemuan/ } \\
\text { Tanggal }\end{array}$} & \multicolumn{4}{|c|}{ Tipe dan nomor pertanyaan } & \multirow{2}{*}{$\begin{array}{c}\text { Total } \\
\%\end{array}$} \\
\hline & & $\begin{array}{c}\text { Tipe } \\
\text { pertanyaan } \\
\text { sempit }\end{array}$ & $\underset{\%}{\mathrm{Jml} /}$ & $\begin{array}{c}\text { Tipe } \\
\text { pertanyaa } \\
\text { n luas }\end{array}$ & $\mathrm{Jml} / \%$ & \\
\hline 1 & $\begin{array}{c}\mathrm{I} . \\
18 \text { maret } \\
2008\end{array}$ & $\begin{array}{c}1,2,3,4,5,7 \\
8,9,11,12 \\
13,15,16 .\end{array}$ & $\begin{array}{c}13= \\
13,13 \%\end{array}$ & $\begin{array}{c}6,10,14, \\
17, \\
18,19,20\end{array}$ & $7=7,7 \%$ & $\begin{array}{c}20= \\
20,20 \\
\%\end{array}$ \\
\hline 2 & $\begin{array}{c}\text { II . } \\
25 \text { Maret } \\
2008\end{array}$ & $\begin{array}{c}1,2,3,4,5 \\
7,8,10,11 \\
13,14,16 \\
17,21,23\end{array}$ & $\begin{array}{c}15= \\
15,15 \%\end{array}$ & $\begin{array}{c}6,9, \\
12,15,16, \\
18,19,20, \\
24 .\end{array}$ & $9=9,9 \%$ & $\begin{array}{c}24= \\
24,24 \\
\%\end{array}$ \\
\hline 3 & $\begin{array}{c}\text { III. } \\
15 \text { April } \\
2008\end{array}$ & $\begin{array}{c}1,3,5,7,8 \\
9,10,11,14, \\
16,20,21 \\
22\end{array}$ & $\begin{array}{c}13= \\
13,13 \%\end{array}$ & $\begin{array}{c}2,4,6,12 \\
13,15,17 \\
18,19\end{array}$ & $9=9,9 \%$ & $\begin{array}{c}22= \\
22,22 \\
\%\end{array}$ \\
\hline 4 & $\begin{array}{c}\text { IV. } \\
29 \text { April } \\
2008\end{array}$ & $1,4,5,9$. & $\begin{array}{c}4= \\
4,4 \%\end{array}$ & $\begin{array}{c}2,3,6,7 \\
8,10 .\end{array}$ & $6=6,6 \%$ & $\begin{array}{c}10= \\
10,10 \\
\%\end{array}$ \\
\hline 5 & $\begin{array}{l}\text { V. } 6 \mathrm{Mei} \\
2008\end{array}$ & $\begin{array}{c}2,3,4,5,9, \\
11,13,14,\end{array}$ & $\begin{array}{c}17= \\
17,17 \%\end{array}$ & $\begin{array}{c}1,6,7,8 \\
10,12 .\end{array}$ & $6=6,6 \%$ & $23=$ \\
\hline
\end{tabular}




\begin{tabular}{|c|c|c|c|c|}
\hline & $\begin{array}{l}15,16,17 \\
18,19,20 \\
21,22,23\end{array}$ & & & $\begin{array}{c}23,23 \\
\%\end{array}$ \\
\hline Jumlah & & $\begin{array}{c}62= \\
62,62 \%\end{array}$ & $\begin{array}{c}37= \\
37,37 \%\end{array}$ & $\begin{array}{c}99= \\
100 \%\end{array}$ \\
\hline
\end{tabular}

Berdasarkan data yang dipaparkan di atas, dapat disimpulkan bahwa dalam lima kali pertemuan guru mengajukan sebanyak 99 buah pertanyaan dalam interaksi belajar-mengajar bahasa Indonesia. Ke- 99 pertanyaan tersebut terdiri atas, $62=$ $62,62 \%$ tipe pertanyaan sempit dan $37=37,37 \%$ tipe pertanyaan luas. Dengan demikian, guru lebih banyak mengajukan tipe pertanyaan sempit dibandingkan tipe pertanyaan luas dalam interaksi belajar-mengajar bahasa Indonesia. Kenyataan ini menunjukkan bahwa guru ketika melaksanakan proses belajar-mengajar kurang mampu memanfaatkan pertanyaan untuk meningkatkan komunikasi di kelas sehingga siswa kurang terlatih agar terampil menggunakan bahasa sebagai alat komunikasi terutama dalam menjawab pertanyaan guru dalam interaksi belajar mengajar bahasa Indonesia. Dalam kondisi seperti ini, partisipasi siswa pun dalam proses belajar-mengajar menjadi rendah. Hal ini disebabkan oleh karena tipe pertanyaan sempit hanya menuntut jawaban singkat dan pendek. Dengan demikian, siswa kurang diberi kesempatan untuk menggunakan bahasa dalam mewahanai perasaan dan pikirannya untuk menjawab pertanyaan guru. Dengan demikian, tujuan pembelajaran bahasa yaitu mampu dan terampil menggunakan bahasa dalam berkomunikasi tidak tercapai. Selama lima kali pertemuan, hanya pada pertemuan ke empat guru lebih banyak mengajukan tipe pertanyaan luas sehingga keadaan kelas menjadi lebih interaktif dan komunikatif.

\section{b. Analisis pertanyaan berdasarkan taksonomi Bloom}

Dalam penelitian ini tidak semua data pertanyaan guru dapat diklasifikasikan ke dalam keenam tingkatan kognitif yang dikemukakan oleh Bloom. Oleh karena itu, pertanyaan-pertanyaan yang dianalisis adalah pertanyaan pertanyaan yang bisa dikelompokkan ke dalam keenam tingkatan kognitif tersebut.

Berdasarkan data hasil penelitian dapat dikemukakan bahwa dalam lima kali pertemuan ada 99 buah pertanyaan sebagai data terpilih yang diajukan oleh guru dalam interaksi belajar-mengajar bahasa Indonesia. Dari 99 pertanyaan yang 
diajukan oleh guru tersebut, hanya 93 pertanyaan yang dapat digolongkan ke dalam keenam tingkatan kognitif taksonomi Bloom dan 6 pertanyaan merupakan pertanyaan sapaan atau ajakan. Ke- 93 pertanyaan yang dapat digolongkan ke dalam tingkatan kognitif taksonomi Bloom dapat dibuatkan rincian sebagai berikut.

Tabel 02. Tingkatan kognitif pertanyaan yang diajukan oleh guru dalam interaksi belajar-mengajar Bahasa Indonesia

\begin{tabular}{|c|c|c|c|c|c|c|c|}
\hline No & $\begin{array}{c}\text { Tingkatan } \\
\text { kognisi }\end{array}$ & $\begin{array}{l}\text { P. I/ No. } \\
\text { Pertanya- } \\
\text { an }\end{array}$ & $\begin{array}{l}\text { P. II/No. } \\
\text { Pertanya- } \\
\quad \text { an }\end{array}$ & $\begin{array}{l}\text { P.III/No. } \\
\text { Pertanya- } \\
\text { an }\end{array}$ & $\begin{array}{l}\text { P.IV/No. } \\
\text { Pertanya- } \\
\text { an }\end{array}$ & $\begin{array}{l}\text { P.V/No. } \\
\text { Pertanya- } \\
\quad \text { an }\end{array}$ & $\underset{\%}{\mathbf{j m l} /}$ \\
\hline 1 & $\begin{array}{l}\text { Pengetahu- } \\
\text { an }\end{array}$ & $\begin{array}{c}1,2,3,4,5, \\
6,7,8,9, \\
11,1213,15\end{array}$ & $\begin{array}{c}1,2,3,4,8 \\
15,21 \\
23\end{array}$ & $\begin{array}{c}1,4,8,9 \\
10,11,16\end{array}$ & $1,2,5$ & $\begin{array}{c}1,2,3,7 \\
16,17, \\
18,19,22\end{array}$ & $\begin{array}{c}40= \\
43,01 \\
\%\end{array}$ \\
\hline 2 & $\begin{array}{l}\text { Pemaham- } \\
\text { an }\end{array}$ & $\begin{array}{c}10,14,16 \\
17,18,19\end{array}$ & $\begin{array}{l}5,7,9,10, \\
11,12,18, \\
19,20,22\end{array}$ & $\begin{array}{c}2,3,5,6,7 \\
12,13,15 \\
17,19 \\
20,21,22\end{array}$ & $\begin{array}{c}3,4,6,8, \\
10\end{array}$ & $\begin{array}{c}5,6,9,10 \\
14,15 \\
21,23\end{array}$ & $\begin{array}{c}42= \\
45,16 \\
\%\end{array}$ \\
\hline 3 & Aplikasi & 0 & 0 & 0 & 0 & 3,20 & $\begin{array}{c}2= \\
2,15 \%\end{array}$ \\
\hline 4 & Analisis & 0 & 0 & 0 & 0 & 8 & $\begin{array}{c}1= \\
1,07 \%\end{array}$ \\
\hline 5 & Sintesis & 0 & 6 & 18 & 9 & 12 & $\begin{array}{c}4= \\
4,30 \%\end{array}$ \\
\hline 6 & Evaluasi & 20. & $16,17,24$ & 0 & 0 & 0 & 4 \\
\hline & Jumlah & 20 & 22 & 21 & 9 & 21 & $\begin{array}{c}93= \\
100 \%\end{array}$ \\
\hline
\end{tabular}

Keterangan

$$
\begin{array}{ll}
\mathrm{PI} & =\text { pertemuan pertama } \\
\mathrm{P} \text { II } & =\text { pertemuam ke dua } \\
\mathrm{P} \mathrm{III} & =\text { petemuan ke tiga } \\
\mathrm{P} \mathrm{IV} & =\text { pertemuan ke empat } \\
\mathrm{PV} & =\text { pertemuan ke lima }
\end{array}
$$

Berdasarkan data tersebut di atas, dapat disimpulkan bahwa guru dalam melaksanakan proses belajar-mengajar bahasa Indonesia memanfaatkan pertanyaan untuk meningkatkan aktivitas dan kreativitas siswa selama proses belajar-mengajar berlangsung. Pertanyaan guru mayoritas pertanyan berpikir tingkat rendah yaitu 84 buah $=90,32 \%$ dan pertanyaan berpikir tingkat tinggi hanya 9 buah $=9,67 \%$. 
Dengan demikian, pertanyaan guru dalam proses belajar mengajar bahasa Indonesia hanya bersifat mengigat kembali apa yang sudah pernah diketahui atau dialami. Pertanyaan seperti ini hanya memiliki satu jawaban yang benar dan menciptakan komunikasi yang tertutup sehingga siswa tidak terlatih untuk terampil menggunakan bahasa dalam menjawab pertanyaan guru. Guru kurang mampu melatih kemampuan berkomunikasi siswa melalui pertanyaan dalam interaksi belajar-mengajar bahasa Indonesia.

\section{c. Analisis pertanyaan berdasarkan fungsinya.}

Data tentang fungsi pertanyaan guru dalam interaksi belajar-mengajar bahasa Indonesia dicari dengan metode wawancara. Dalam melakukan wawancara peneliti mengajukan delapan pertanyaan pokok kepada subjek. Dari delapan pertanyaan tersebut didapatkan data sebagai berikut.

(a) Apakah Anda merencanakan sebelumnya pertanyaan yang Anda ajukan dalam proses belajar-mengajar bahasa Indonesia?

Jawaban guru: Tidak, karena pertanyaan tersebut muncul secara spontan pada saat pembelajaran sedang berlangsung dan sangat bergantung pada situasi, kondisi serta materi pembelajaran. Pertanyaan hanya direncanakan dalam rancangan persiapan pembelajaran.

(b) Apa tujuan Anda mengajukan pertanyaan dalam proses belajar-mengajar bahasa Indonesia?

Jawaban guru: Untuk mengukur ketercapaian indikator yang tertuang dalam rancangan persiapan pembelajaran, memusatkan perhatian siswa, dan membuat situasi pembelajaran menjadi aktif dan kreatif sehingga terjadi interaksi yang optimal di dalam kelas.

(c) Apa fungsi pertanyaan-pertayaan yang Anda ajukan dalam proses belajarmengajar bahasa Indonesia?

Jawaban guru: Sebagai sebuah strategi dalam pembelajaran untuk mengajak siswa berpartisipasi aktif, mengarahkan dan memusatkan pikiran pada materi yang sedang di bahas. Di samping itu, untuk memancing siswa agar mau dan berani berbicara sehingga mereka terlatih mengemukakan pendapat dalam berdiskusi ( berkomunikasi) 
(d) Ada beberapa pertanyaan yang belum selesai Anda ajukan kepada siswa dalam proses belajar-mengajar, Apa fungsi pertanyaan tersebut?

Jawaban guru: Untuk memancing siswa berpikir dengan cepat, tepat, dan cermat sehingga siswa terlatih berpikir cepat dan tepat, terlatih berbicara cepat dan tepat dalam mengikuti proses belajar-mengajar

(e) Ada beberapa kali Anda mengulangi jawaban siswa, kemudian Anda bertanya lewat jawaban siswa, Apa fungsi pertanyaan tersebut?

Jawaban guru: Untuk memberikan penekanan dan menggali pedapat siswa yang lain, meyakinkan siswa terhadap jawaban yang diberikan, dan mengembangkan daya nalar siswa sehingga siswa dapat dan berani mengemukakan pendapatnya secara leluasa, berstruktur dan sistematis.

(f) Ada beberapa pertanyaan yang Anda ajukan kepada siswa, tetapi Anda tidak menuntut jawaban siswa, Apa fungsi pertanyaan tersebut?

Jawaban guru: Pertanyaan tersebut hanya berfungsi memberikan penekanan kepada siswa dan siswa sudah tahu pasti jawaban yang diharapkan oleh guru.

(g) Apa yang Anda gunakan sebagai dasar untuk mengajukan pertanyaan kepada siswa dalam proses belajar-mengajar bahasa Indonesia?

Jawaban guru: Yang dipakai dasar adalah situasi dan kondisi pembelajaran, materi pembelajaran, lingkungan pembelajaran.

(h) Apakah Anda memahami secara teoretis tentang fungsi pertanyaan yang diajukan dalam proses belajar-mengajar bahasa Indonesia?

Jawaban guru: Saya cukup memahami fungsi pertanyaan dalam pembelajaran karena hal seperti ini banyak didapat baik melalui pendidikan dan pelatihan mau pun melalui buku-buku.

Berdasarkan data tersebut di atas, dapat disimpulkan bahwa guru tidak merencanakan sebelumnya pertanyaan yang diajukan dalam proses belajar-mengajar karena pertanyaan yang diajukan bersifat spontan bedasarkan situasi, kondisi, dan materi pembelajaran. Petanyaan guru dalam proses belajar-mengajar bahasa Indonesia kurang sesuai dengan fungsinya yaitu melatih siswa agar terampil menggunakan bahasa Indonesia dalam berkomunikasi, terutama untuk mewahanai pikirannya. Pertanyaan guru dalam interaksi belajar-mengajar lebih banyak 
diarahkan untuk mengukur hasil belajar yaitu mengukur ketercapaian indikator yang tertuang dalam rancangan persiapan pembelajaran

\section{Pembahasan Hasil Penelitian}

1) Temuan penelitian ini menunjukkan bahwa dalam pembelajaran bahasa Indonesia pada siswa kelas V SD Negeri No. 7 Susut, Bangli, pertanyaan-pertanyaan guru dalam interaksi belajar-mengajar bahasa Indonesia bila dilihat dari tipenya ditemukan 99 buah pertanyaan. Ke- 99 buah pertanyaan tersebut terdiri atas 62 buah tipe pertanyaan sempit $=62,62 \%$ dan 37 buah tipe pertanyaan luas = $37,37 \%$. Hal ini menunjukkan bahwa dalam upaya guru mencapai tujuan pembelajaran bahasa Indonesia, khususnya pembelajaran bahasa Indonesia siswa kelas V Sekolah Dasar, guru sudah memanfaatkan pertanyaan untuk meningkatkan aktivitas dan efektivitas pembelajaran bahasa Indonesia.

2) Temuan penelitian ini menunjukkan bahwa pertanyaan dalam interaksi belajarmengajar bahasa Indonesia pada siswa kelas V Sekolah Dasar Negeri No. 7 Susut, Bangli mayoritas pertanyaan berpikir tingkat rendah (berupa pertanyaan pengetahuan dan pemahaman) yaitu sebayak 84 buah $=90,32 \%$. Pertanyaan berpikir tingkat tinggi sebanyak 8 buah $=9,80$.

Temuan penelitian ini menunjukkan bahwa terfokusnya pertanyaan yang diajukan oleh guru pada tingkatan berpikir tingkat rendah mungkin disebabkan oleh rumusan indikator yang dituangkan dalam rancangan persiapan pembelajaran dan materi yang diajarkan. Rumusan indikator yang dituangkan dalam rancangan persiapan pembelajaran hampir seluruhnya dengan kata-kata operasional menyebutkan, memahami, dan membuat. Dalam proses belajarmengajar indikator merupakan rambu-rambu tujuan pembelajaran yang harus dicapai. Tujuan pembelajaran akan mengilhami pertanyaan oleh guru dalam interaksi belajar-mengajar. Guru sulit membedakan pertanyaan yang bertujuan untuk mengukur hasil pembelajaran dengan pertanyaan yang bertujuan untuk meningkatkan interaksi dan komunikasi dalam proses belajar-mengajar. Di lain pihak, ruang lingkup dan kemendalaman materi yang diajarkan juga mempengaruhi kualitas pertanyaan yang diajukan oleh guru dalam interaksi belajar-mengajar. 
3) Berdasarkan data hasil wawancara yang dilaksanakan setelah melakukan observasi dan rekaman seperti dipaparkan di atas, dapat dikemukakan bahwa guru dalam melaksanakan proses belajar-mengajar bahasa Indonesia tidak merencanakan pertanyaan sebelumnya, karena pertanyaan yang diajukan bersifat spontan. Hal seperti itu berakibat pertanyaan yang diajukan oleh guru dalam interaksi belajar-mengajar bahasa Indonesia kurang terfokus pada tujuan untuk meningkatkan efektivitas pembelajaran bahasa Indonesia. Tujuan guru mengajukan pertanyaan dalam proses belajar-mengajar bahasa Indonesia lebih banyak terarah kepada pencapaian indikator yang dituangkan dalam rancangan persiapan pembelajaran dan kurang melatih siswa terampil menggunakan unsurunsur bahasa Indonesia dalam berkomunikasi.

\section{SIMPULAN DAN SARAN}

\section{Simpulan}

Berdasarkan fakta-fakta yang berhasil ditemukan dan pembahasan hasil penelitian, maka dapat disimpulkan:

1) Tipe pertanyaan guru kelas V SD Negeri No. 7 Susut, Bangli dalam interaksi belajar-mengajar bahasa Indonesia adalah tipe pertanyaan sempit dan tipe peranyaan luas. Tipe pertanyaan sempit sebanyak 72 buah $=61,53 \%$ dan tipe pertanyaan luas sebanyak 45 buah $=38,49 \%$. Pertanyaan guru dalam interaksi belajar-mengajar cenderung kepada tipe pertanyaan sempit.

2) Tingkatan kognitif pertanyaan guru Kelas V SD Negeri No. 7 Susut, Bangli dalam interaksi belajar-mengajar bahasa Indonesia sudah mencapai keenam tingkatan kognitif taksonomi Bloom. Apabila dilihat dari sebarannya pertanyaan guru terfokus pada dua tingkatan berpikir tingkat rendah yaitu pengetahuan dan pemahaman. Hal ini menunjukkan guru kurang mampu memanfatkan pertanyaan untuk menumbuhkembangkan daya pikir kritis dan kreatif siswa dalam memecahkan masalah.

3) Pertanyaan guru kelas V SD Negeri No. 7 Susut, Bangli kurang sesuai dengan fungsi pertanyaan dalam interaksi belajar-mengajar bahasa Indonesia. Karena dengan pertanyaannya guru kurang mampu mengarahkan proses berpikir siswa untuk menemukan masalah yang dibahas, menggali kemampuan siswa untuk 
meningkatkan kuantitas dan kualitas jawaban dari pertanyaan semula, dan memancing ide-ide siswa yang asli, serta memberikan penekanan pada bagian yang dianggap penting dengan pertanyaan retoris. Pertanyaan guru dalam interaksi belajar-mengajar bahasa Indonesia lebih banyak untuk mengevaluasi hasil belajar.

\section{Saran}

1) Dalam melaksanakan proses belajar-mengajar, guru perlu meningkatkan pengetahuan dan keterampilan bertanyanya dalam interaksi belajar-mengajar bahasa Indonesia sehingga kuantitas dan kualitas pertanyaannya menjadi lebih meningkat.

2) Tipe pertanyaan guru dalam proses belajar-mengajar bahasa Indonesia sebaiknya lebih banyak tipe pertanyaan luas sehingga dapat menumbuhkembangkan kemampuan siswa dalam berkomuniasi dan berinteraksi di dalam kelas.

3) Guru hendaknya berusaha meningkatkan kemampuan dan pengetahuannya agar dapat membedakan pertanyaan untuk mengevaluasi hasil belajar dan pertanyaan untuk meningkatkan efektivitas pembelajaran bahasa Indonesia.

4) Pemerintah berusaha menyelipkan program pendidikan khusus mengenai keterampilan bertanya guru dalam proses belajar-mengajar bahasa Indonesia melalui penataran atau pelatihan secara berkesinambungan.

\section{DAFTAR PUSTAKA}

Aminudin. M. 1990. Pengembangan Penelitian Kualitatif dalam Bidang Bahasa dan Sastra. Malang : HISKI Komisriat Malang dan YA3.

Baradja, M F. 1990. Kapita Selekta Pengajaran Bahasa. Malang: IKIP Malang.

Bloom, B.S. 1956 Taxonomy of Educational Objectives: Handbook I Cognitive Domain. London: Longman.

Brown, George.1984. Micro Teaching : A Programme of Teaching in the Middle and Secondary Schools: Planning for Competence. USA: Macmillan Publishing Co. Inc. 
Depdikbud. 1991. Pedoman Proses Belajar-Mengajar di Sekolah Dasar. Jakarta: Proyek Pembinaan Sekolah Dasar.

Frasee, Bruce M. dan Rudnitski, Rose A.1995. Integrated Teaching Method: Theory, Classroom Aplications, and Field-Based Connections. Albany: Dalmar Publishers.

Gosong, I Made. 1998. Pertanyaan yang Diajukan oleh Guru dalam Pembelajaran Membaca. Disertasi tidak diterbitkan Malang: IKIP Malang.

Kristiantari, Rini. 1997. Pertanyaan Guru dalam Pembelajaran Bahasa Indonesia di Sekolah Dasar. Tesis Tidak diterbitkan. Malang: IKIP Malang.

Priyanti, Endah Tri. 1993. Karakteristik Interaksi Belajar-Mengajar Bahasa Indonesia. Malang: IKIP Malang.

Roffi, udin,AH. 1990. Studi Tentang Bentuk Pertanyaan dalam Interaksi BelajarMengajar Kelas Bahasa Indonesia dan dalam Keluarga. Malang: Tesis Tidak Diterbitkan. IKIP Malang.

Sulo, La. S.L. Sugeng Paranto dan Soedirdjo dkk. 1980. Micro-Teaching. Jakarta: Proyek Pengembangan Pendidikan Guru (P3G) Departemen Pendidikan dan Kebudayaan.

Tim Penyusun KTSP. 2007. Kurikulum Tingkat Satuan Pendidikan Sekolah Dasar Negeri No 7 Susut Bangli. Bangli: Dinas Pendidikan Kabupaten Bangli. 